\title{
KONSEP ARSITEKTUR ISLAMI SEBAGAI SOLUSI DALAM PERANCANGAN ARSITEKTUR
}

Munichy Bachroon Edrees

\author{
Jurusan Arsitektur, Fakultas Teknik Sipil dan Perencanaan, \\ Universitas Islam Indonesia, Yogyakarta, Indonesia \\ e-mail: unich_leo@yahoo.co.id
}

\begin{abstract}
In many Qur'anic verses and Hadith, the term 'to construct' or 'to build' is frequently mentioned. It means that there are some principles in this kind of activity in Islam, that can be called Islamic principal of architecture. Therefore, it is very important for Muslim architects to have a deep understanding about these principals, and to bring them to the operational level. Basically, to build it to make some social, technical, economical, and psychological arrangements. Great changes that occur within the relationship of human and their environment in fact influence the way architects deal with these arrangements. Islamic principal of architecture give Muslim architects a basis in their architectural activities that derived from the Qur'an and Hadith. Based on these principals, the arrangements will have to considerate hablumminallah, hablumminannaas, and hablumminal'alam, which are the core of the Islamic relationships. The result of these arrangements then could be applied in five important things in architecture: function, form, technology, safety, and comfort, with a deep consideration in contextuality and eficiency.
\end{abstract}

Keywords: Principle of architecture, islamic values, al-Qur'an, al-Hadith

\begin{abstract}
Abstrak
Di dalam al-Qur'an dan al-Hadits banyak disebutkan tentang kata "membangun". Hal tersebut menunjukkan bahwa terdapat beberapa prinsip bagi kegiatan membangun ini di dalam Islam. Untuk itu, sudah seharusnya sebagai arsitek muslim kita menerapkan prinsip-prinsip islami dalam berarsitektur. Membangun pada dasarnya adalah melakukan pengaturan baik pengaturan sosial, teknik, ekonomi, dan psikologis. Dengan terjadinya perubahan-perubahan besar dalam hubungan antara masyarakat dengan lingkungan, tujuan arsitektur harus diubah. Arsitektur harus bersifat islami, harus sesuai dengan al-Qur'an dan al-Hadits, sehingga "pengaturan" yang dilakukan di dalam arsitektur mampu menjamin hubungan manusia dengan Allah (hablumminallah), hubungan manusia dengan lingkungan alam (hablumminal'alamin), dan hubungan manusia dengan manusia (hablumminannas) ke arah yang lebih baik. Pengaturan tersebut nantinya akan menghasilkan sebuah konsep arsitektur islami yang sesuai dengan al-Qur'an dan al-Hadits, yang mampu mencakup lima hal penting yaitu fungsi, bentuk, teknik, keamanan, dan kenyamanan, yang kesemuanya harus mempertimbangkan kontekstualitas dan efisiensi.
\end{abstract}

Kata kunci: Prinsip arsitektur, nilai-nilai Islam, al-Qur’an, al-Hadits

\section{Pendahuluan: Islam dan Arsitektur}

Menurut Ibn Katsir, salah seorang Mufassir, bahwa agama (ad-din) Islam adalah syariat (peraturan hukum) yang ditetapkan oleh Allah. Agama bisa juga disebut dengan syara', syariat, atau millah. Peraturan hukum ini wajib ditaati. Kata Islam dapat ditemukan di dalam beberapa ayat alQur'an, diantaranya adalah sebagai berikut:

"Bahwasanya agama yang diakui di sisi Allah hanyalah Islam."1

"Dan barangsiapa yang mencari selain Islam untuk menjadi agamanya, maka tidaklah diterima agama itu baginya, dan orang itu di hari akhirat termasuk orangorang yang rugi." 2

"Dan Aku hanya rela Islam itu yang menjadi agama bagimu." 3

16 | Journal of Islamic Architecture Volume 1 Issue 1 June 2010
Ketiga ayat tersebut selain menjadi dasar bagi penempatan Islam untuk agama yang dibawa oleh Nabi Muhammad saw, juga menjadi penegas bahwa hanya Islam, agama yang benar dan diridhai oleh Allah swt. Hakikat agama mencakup tiga unsur pokok, yaitu itikad (iman), akhlak (moral), dan amal saleh (amal kebajikan). Ketiga unsur pokok ini merupakan satu kesatuan yang tidak terpisahkan, artinya itikad berfungsi jika disertai oleh akhlak yang mulia dan beramal saleh. Demikian juga sebaliknya, berbuat kebajikan dan bermoral mulia tanpa disertai oleh iman yang benar belumlah termasuk dalam kategori beragama.

Maksud diturunkannya agama ialah agar umat manusia mendapat pedoman dan penuntun untuk memperoleh kebahagiaan hidup di dunia serta kebahagiaan di akhirat kelak. Kebahagiaan di akhirat hanya bisa diperoleh jika seseorang dipersilahkan Allah masuk ke surga Jannatul Khulud. Dengan 
demikian, agama itu mengatur semua aktivitas manusia di dunia, tidak terbatas hanya mengatur persoalan ibadah maghdhah (sholat, puasa, zakat, dan haji) saja, akan tetapi juga persoalan-persoalan ibadah yang sifatnya ghairu maghdhah (muamalah), termasuk dalam berarsitektur. Ini semua sesuai dengan firman Allah swt sebagai berikut:

"Aku tidak menciptakan jin dan manusia kecuali agar mereka beribadah kepada-Ku. "

Dengan demikian, apapun yang dilakukan oleh manusia di muka bumi ini hanyalah beribadah kepada Allah swt. Termasuk di dalamnya adalah berarsitektur. Berarsitektur merupakan salah satu aktivitas manusia yang juga dibingkai dalam ruang lingkup ibadah kepada Allah swt, sehingga dalam berarsitektur mestinya kita selalu berpedoman kepada al-Qur'an dan as-Sunnah. Salah satunya adalah pemahaman bahwa Islam adalah agama yang rahmatan lil 'alamin, artinya memberikan rahmat, berkah, maslahat, dan manfaat bagi alam semesta. Karena itu, di dalam berarsitektur mestinya kita juga mampu menjadikan hasil rancangan kita sebagai arsitektur yang rahmatan lil 'alamin bagi lingkungan dimana bangunan itu berdiri dan tidak menimbulkan dampak negatif (mudharat) terhadap lingkungan yang mengakibatkan rusaknya ekosistem di lingkungan tersebut.

Hal ini menunjukkan bahwa Islam bukan semata-mata mengurusi akhirat, melainkan merupakan sebuah way of life, artinya apapun yang dilakukan oleh manusia di muka bumi ini diatur di dalam Islam. Rasulullah bersabda di dalam salah satu hadits yang diriwayatkan oleh Imam Muslim, sebagai berikut:

"Aku tinggali kamu sekalian dua perkara, kalau kamu berpegang kepada dua perkara itu, kamu akan selamat di dunia dan di akhirat, dan dua perkara itu adalah Qur'an dan Sunnah". 5

Oleh karena itu, segala aktivitas kita termasuk dalam berarsitektur, tetaplah merujuk kepada alQur'an dan as-Sunnah sehingga tercipta desain yang baik dan tepat.

\section{Arsitektur yang Islami}

Terdapat cukup banyak teori yang membahas tentang arsitektur, baik yang menganggap bahwa arsitektur hanya sekadar terdiri atas ruang, bentuk dan struktur saja, maupun yang mengatakan bahwa sebuah ruang merupakan unsur paling penting di dalam arsitektur, sehingga untuk memahami arsitektur diperlukan pemahaman atas ruang. Ada juga yang mempunyai pendapat bahwa arsitektur adalah permainan massa dan cahaya yang luar biasa. Mata kita memang diciptakan untuk melihat bentuk-bentuk yang diterangi oleh cahaya. Cahaya dan bayangan mengungkapkan bentuk-bentuk tertentu, seperti kubus, kerucut, silinder, dan sebagainya. Karenanya, timbullah anggapan bahwa arsitektur selalu berhubungan dengan bentuk-bentuk yang indah. Pengertian-pengertian tersebut bisa jadi berkaitan dengan apa yang disabdakan oleh Nabi Muhammad saw, "Sesungguhnya Allah itu indah dan mencintai keindahan"6.

Teori-teori tentang apa dan bagaimana arsitektur bukanlah persoalan besar, namun yang terpenting adalah memperhatikan bagaimana arsitektur mampu memberikan kepuasan bagi penggunanya. Vitruvius membuat pernyataan bahwa tujuan menciptakan arsitektur adalah untuk penyusunan, penataan, dan keselarasan dalam pergerakan, simetri, kesesuaian, dan ekonomi. Para ahli teori berikutnya telah mengembangkan varianvarian sistem untuk mengidentifikasi sasaran-sasaran dalam perancangan arsitektur. Perkembangan ilmuilmu sosial pada abad ke-19 dan abad ke-20 telah menyuburkan tumbuh kembangnya sistem-sistem yang dipakai untuk mencapai tujuan arsitektur. Membangun tak lain adalah pengaturan sosial, teknik, ekonomi, dan pengaturan psikologis. Arsitektur yang kita alami dan kita huni mempunyai banyak peran, yang kesemuanya merupakan manifestasi dari perilaku hidup kita sehari-hari, cermin dari kebudayaan kita. Hal ini juga sangat dipengaruhi oleh tingkat perasaan akan keindahan (taste) kita, sehingga mampu menggambarkan tingkat kemajuan teknologi yang kita miliki, tingkat kemakmuran, juga dapat bercerita tentang struktur sosial masyarakat. Kita juga dapat mengharapkan bahwa dengan terjadinya perubahan-perubahan besar dalam hubungan antara masyarakat dengan lingkungan, pernyataan tujuan arsitektur harus diubah, menjadi sebuah keselarasan di antara keduanya.

Pada penjabaran sebelumnya sudah dijelaskan bahwa Islam adalah agama yang rahmatan lil 'alamin. Artinya, agama yang memberikan rahmat bagi seluruh alam semesta dan seisinya. Oleh karena itu, sudah semestinya dalam merancang para arsitek muslim senantiasa berusaha agar rancangannya bermakna, memberikan manfaat bagi lingkungan atau kawasan dimana bangunan itu didirikan. Lebih jauh, harus dihindari pula merancang bangunan yang tidak bermanfaat bagi masyarakat, yang justru mendekatkan kepada kemubadziran. Kemubadziran adalah hal yang bertentangan dengan ajaran Islam, artinya dalam merancang suatu bangunan setiap arsitek harus berusaha untuk mewujudkan desain arsitektur yang tepat guna dan tidak berlebihlebihan, seperti dinyatakan di dalam hadits riwayat Imam Muslim berikut:

"Jikalau akan melakukan suatu urusan, pertimbangkanlah manfaat dan mudharatnya, kalau urusan itu bermanfaat kerjakanlah akan tetapi jikalau urusan itu banyak mudharatnya tinggalkanlah." ${ }^{7}$ 
Hakekatnya semua arsitektur didesain dengan tujuan tepat guna. Akan tetapi dengan kemungkinan adanya beberapa faktor, hasil akhirnya belum tentu memberi "guna" maksimal seperti apa yang di harapkan. Keberhasilan arsitektur, semestinya dinilai bukan hanya pada bentuk akhir perwujudan dan desainnya, melainkan apakah ia mampu dan berhasil memberikan pengaruh yang baik terhadap penghuni dan lingkungan dimana arsitektur itu berada. Oleh karena itu, seperti telah diungkapkan di atas, desain/rancangan harus selalu berorientasi tepat guna dan "well-tasted", yaitu sesuai atau cocok bagi penghuninya dan mempunyai pengaruh yang positif pada lingkungannya.

Sikap yang bijaksana adalah belajar dari masyarakat dan alam, memperluas wawasan kita, untuk mencari informasi yang perlu kita jadikan masukan bagi desain tepat guna, karena banyak sekali dalam al-Qur'an maupun al-Hadits yang menganjurkan kita untuk selalu melakukan segala sesuatunya harus mempunyai manfaat ataupun maslahat bagi masyarakat, seperti dalam salah satu hadits di atas.

\section{Pertimbangan dalam Perancangan Arsitektur}

Seorang arsitek dalam merancang sangat dianjurkan untuk mengikuti lima langkah merancang arsitektur atau mengikuti prinsip-prinsip The Five Stars in Architectural Design, seperti dalam gambar di bawah ini:

\section{FIVE PRINCIPLES IN ARCHITECTURE}

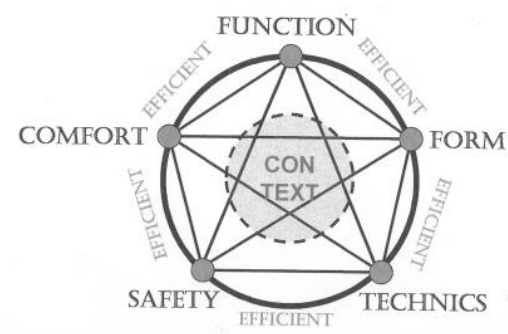

Gambar 1. Lima Prinsip dalam Arsitektur (Sumber: Munichy B. Edrees)

Penjelasan dari kelima prinsip di atas beserta dua faktor lainnya (context dan efficient) yang harus dipertimbangkan dalam perancangan arsitektur adalah sebagai berikut:

\section{Fungsi (Function)}

Pertimbangan terhadap fungsi bangunan. Artinya, fungsi merupakan yang harus diprioritaskan awal. Semua desain arsitektur apapun itu harus berfungsi dengan baik. Arsitektur adalah sebuah wadah yang mewadahi kegiatan manusia di dalamnya, artinya kalau kegiatannya berubah secara logika wadahnya juga berubah (menyesuaikan dengan kegiatannya). Masjid mewadahi kegiatan manusia beribadah sholat, pengajian, kegiatankegiatan rohani, dan lain sebagainya; mall mewadahi kegiatan manusia berjual-beli, rekreasi dan lain sebagainya; kampus mewadahi kegiatan manusia belajar mengajar, dan lain sebagainya.

\section{Bentuk (Form)}

Pertimbangan terhadap bentuk bangunan. Bentuk sangat berhubungan dengan estetika, termasuk penggunaan warna material dan sebagainya, sehingga bentuk juga perlu dipertimbangkan untuk mendapatkan citra yang diinginkan oleh si arsitek.

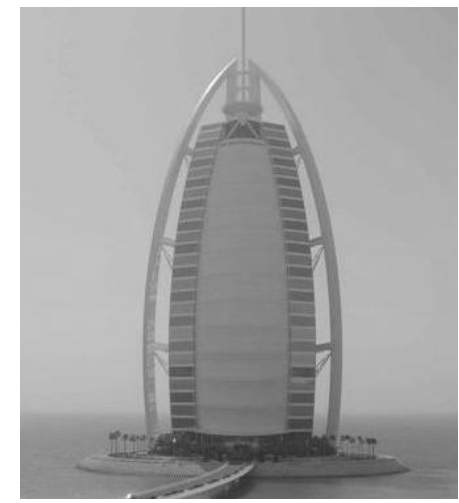

Gambar 2. Bentuk bangunan yang mendukung citra hotel

\section{Teknik (Technics)}

Pertimbangan terhadap segi kekuatan bangunan. Karena teknik sangat erat hubungannya dengan kekuatan bangunan seperti struktur, konstruksi, elemen/komponen lain yang mendukung bangunan itu, termasuk penggunaan material dan lain sebagainya.

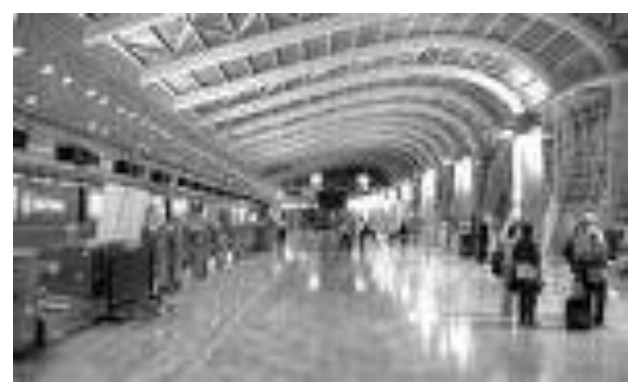

Gambar 3. Struktur bangunan yang mendukung guna sekaligus citra bandar udara (airport)

\section{Keamanan (Safety)}

Pertimbangan keselamatan bangunan terhadap hal-hal yang menyebabkan manusia sebagai pengguna bangunan tersebut tidak selamat, artinya meminimalisasi adanya korban jiwa manusia. Misal terjadi kebakaran, bangunan tersebut harus bisa mengatasi dengan (misal) adanya sprinkler, dimana ketika suhu ruang tinggi atau ada asap, sprinkler 
akan menyemprotkan air sehingga diharapkan api di dalam ruang tersebut akan padam. Selain itu juga harus dipikirkan bagaimana manusia pengguna bangunan tersebut menyelamatkan diri, sehingga perlu adanya fire escape apabila terjadi kebakaran, maupun menyelamatkan diri apabila terjadi gempa bumi. Bangunan juga harus mampu merespon gempa, sehingga meminimalkan kerugian pada pengguna bangunan.

\section{Kenyamanan (Comfort)}

Pertimbangan terhadap kenyamanan bangunan, karena pada prinsipnya, bangunan harus memberikan kenyamanan bagi penggunanya, baik kenyamanan termal maupun kenyamanan visual. Selain itu, perlu diperhatikan pula kenyamanan sirkulasinya. Yang lebih penting sebagai arsitek, harus mampu merancang bangunan yang nyaman, sejuk, sirkulasi udara di dalam ruangan baik serta berdampak positif terhadap lingkungan sekitarnya (ramah lingkungan), tanpa menggunakan alat mekanikal seperti AC, fan, exhauser, dan sebagainya.

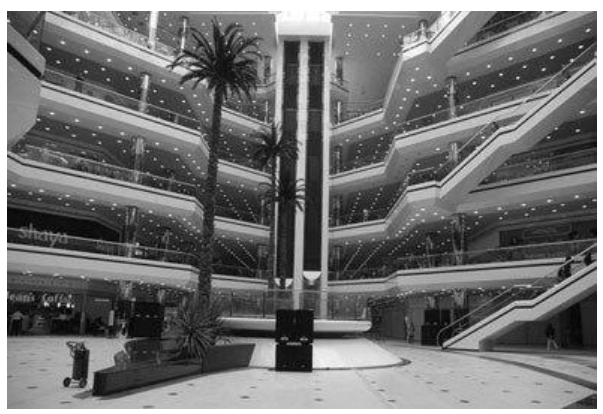

Gambar 4. Mall yang memiliki atrium dengan pencahayaan alami dapat mengurangi konsumsi energi secara signifikan

\section{Konteks (Context)}

Pertimbangan terhadap konteks lingkungan atau kawasan dimana bangunan itu akan didirikan. Bangunan di Yogya lain dengan bangunan di Malang, karena kondisi geografis/alam/budaya/perilaku manusianya berbeda, sehingga seharusnya, tiap daerah mempunyai kekhasan sendiri-sendiri.

\section{Efisien (Efficient)}

Pertimbangan ekonomi bangunan, artinya sedapat mungkin kita dalam membangun bangunan apapun harus efisien, artinya murah dan fungsional.

\section{Tinjauan terhadap Lima Prinsip dalam Arsitektur berdasarkan Nilai-Nilai Islam}

Dalam beraktivitas apapun termasuk dalam merancang, seorang arsitek muslim harus selalu berpegang kepada al-Qur'an dan as-Sunnah agar hasil rancangannya memberikan manfaat. Oleh karena itu, dalam merancang mestinya seorang arsitek mengacu kepada prinsip-prinsip di atas dalam merancang arsitektur. Prinsip-prinsip tersebut dapat kita temukan kesesuaiannya dengan nilai-nilai Islam, sebagai berikut:

\section{Fungsi}

Karya arsitektur harus fungsional, artinya harus bisa dimanfaatkan secara maksimal, menghindari 'kemubadziran'. Seperti telah dijelaskan di atas, kemubadziran atau tindakan berlebih-lebihan merupakan salah satu tindakan yang dibenci Allah dan Rasulullah, serta mengakibatkan banyak kerusakan di muka bumi. Hal ini dinyatakan di dalam al-Qur'an Surat al-A'raaf Ayat 31, “Hai anak Adam, pakailah pakaianmu yang indah di setiap (memasuki) mesjid, makan dan minumlah, dan janganlah berlebih-lebihan. Sesungguhnya Allah tidak menyukai orang-orang yang berlebih-lebihan."8

\section{Bentuk}

Bangunan dapat mempunyai tampilan bentuk yang bagus namun tetap fungsional dan tidak berlebih-lebihan, seperti yang dicontohkan oleh setiap ciptaan Allah di muka bumi yang mengandung keindahan sekaligus kemanfaatan, seperti dinyatakan di dalam Surat Shaad Ayat 27, "Dan Kami tidak menciptakan langit dan bumi dan apa yang ada antara keduanya tanpa hikmah...". 9

\section{Teknik}

Bangunan harus mempunyai struktur dan konstruksi yang kokoh dan kuat sehingga tidak membahayakan manusia yang menggunakannya. Allah telah menjadikan benda-benda ciptaan-Nya sebagai potensi yang dapat dimanfaatkan oleh manusia dalam mendirikan bangunan yang kokoh, misalnya bahan baja yang terdapat di dalam alQur'an Surat Al-Hadiid Ayat 25, “Kami turunkan besi yang di dalamnya mempunyai tenaga yang sangat dahsyat dan berbagai manfaat bagi manusia" ${ }^{10}$. Namun, seiring dengan kemajuan teknologi, yang berarti juga kemajuan teknik dalam bangunan dan struktur, arsitek harus mampu menggunakan material-material ramah lingkungan dan yang mempunyai recycling life yang cepat dan dapat diperbarui, memanfaatkan bahan-bahan daur ulang, serta mampu mengkombinasikan penggunaan baja dengan bahan-bahan tersebut, sehingga meminimalisasi material yang terbuang saat proses pembangunan.

\section{Keselamatan}

Karya arsitektur harus mampu menjamin keselamatan penghuninya seandainya terjadi bencana/musibah apapun sebagai salah satu wujud ikhtiar, seperti pesan Nabi dalam Hadits Riwayat Abu Dawud, "Mintalah selalu keselamatan kepada Allah swt" $"$.

\section{Kenyamanan}


Karya arsitektur harus mampu memberikan kenyamanan bagi penghuninya, sehingga penghuni selalu bersyukur atas kenikmatan yang diberikan Allah, seperti nikmat diberi udara dan pencahayaan alami, seperti dinyatakan di dalam al-Qur'an Surat Ibrahim Ayat 7, "Sesungguhnya jika kamu bersyukur, pasti Kami akan menambah (nikmat) kepadamu, dan jika kamu mengingkari (nikmat-Ku), maka sesungguhnya azab-Ku sangat pedih" ${ }^{12}$.

\section{Konteks}

Karya arsitektur harus mampu menyatu dengan lingkungan dimana arsitektur itu didirikan, artinya tidak merusak lingkungan alam maupun lingkungan buatan. Hal ini dinyatakan di dalam al-Qur'an Surat al-Qashash Ayat 77, “....dan janganlah kamu berbuat kerusakan di (muka) bumi. Sesungguhnya Allah tidak menyukai orang-orang yang berbuat kerusakan"13.

\section{Efisien}

Karya arsitektur harus efisien, misalnya dengan prinsip "luxurious in simplicity", artinya mewah dalam desain tapi murah dalam pendanaannya, sehingga menghindari kemubadziran. "Sesungguhnya pemboros-pemboros itu adalah saudara-saudara syaitan dan syaitan itu adalah sangat ingkar kepada Tuhannya."14

\section{Penutup}

Dari paparan di atas, dapat kita simpulkan bahwa beberapa prinsip arsitektur di atas memiliki keterkaitan yang sangat erat dengan nilai-nilai Islam yang terdapat di dalam al-Qur'an dan al-Hadits. Dengan nilai-nilai islam tersebut di atas, prinsip fungsi, bentuk, teknik, keselamatan, kenyamanan, konteks, dan efisiensi menjadi bingkai dalam merancang karya arsitektur yang bermanfaat, tepat guna, indah, dan tidak menimbulkan kerusakan terhadap lingkungan.

\section{Daftar Pustaka}

1 Zaini Dahlan. 1997. Qur'an Karim dan Terjemahan Artinya. Surat 3: 19. Yogyakarta: UII Press

2 Zaini Dahlan. 1997. Qur'an Karim dan Terjemahan Artinya. Surat 3: 85. Yogyakarta: UII Press

3 Zaini Dahlan. 1997. Qur'an Karim dan Terjemahan Artinya. Surat 5: 3. Yogyakarta: UII Press

4 Zaini Dahlan. 1997. Qur'an Karim dan Terjemahan Artinya. Surat 51: 56. Yogyakarta: UII Press

5,7 Imam Abu Husein Muslim Ibnu Hajjal alQusyairy. 1992. Hadits Shahih Muslim. Semarang: Penerbit Asy-Syifa'
6 Dr. Muhammad Faiz Almath. 2004. 1100 Hadits Terpilih (Sinar Ajaran Muhammad). Jakarta: Gema Insani Press

8 Zaini Dahlan. 1997. Qur'an Karim dan Terjemahan Artinya. Surat 7: 31. Yogyakarta: UII Press

9 Zaini Dahlan. 1997. Qur'an Karim dan Terjemahan Artinya. Surat 38: 27. Yogyakarta: UII Press

10 Zaini Dahlan. 1997. Qur'an Karim dan Terjemahan Artinya. Surat 57: 25. Yogyakarta: UII Press

11 Nasruddin al-Albani. 2006. Hadits Shahih Abu Dawud. Jakarta: Pustaka Azzam

12 Zaini Dahlan. 1997. Qur'an Karim dan Terjemahan Artinya. Surat 14: 7. Yogyakarta: UII Press

13 Zaini Dahlan. 1997. Qur'an Karim dan Terjemahan Artinya. Surat 28: 77. Yogyakarta: UII Press

14 Zaini Dahlan. 1997. Qur'an Karim dan Terjemahan Artinya. Surat 17: 27. Yogyakarta: UII Press 